\title{
Examining the Attitudes and Problem Solving Skills of Physical Education and Sports Students ${ }^{i}$
}

\author{
Ayşe Feray Özbal", Kerim Balıbey, Ali Meral, Sinan Alıç \\ School of Physical Education and Sport, Kastamonu University, Turkey
}

Copyright@2019 by authors, all rights reserved. Authors agree that this article remains permanently open access under the terms of the Creative Commons Attribution License 4.0 International License

\begin{abstract}
This study was conducted to explore attitudes and problem solving skills of physical training and sports students. The participants of the study were 260 students (111 female and 149 male) attending Kastamonu University School of Physical Training and Sports. The data collection tools used in the study were personal information form prepared by the researchers, Scale of Attitudes of Preservice Teachers Towards Teaching Profession, whose validity and reliability studies were conducted (1) and Problem Solving Inventory, which was developed (2) and adapted to Turkish language (2). The analyses revealed no significant difference for "gender", "age", "family income level", and "class level" variables; however, a significant difference was found for the variable "educational background of parents". In addition, simple linear correlation analysis of the scores of attitude and problem solving dimensions showed a low level of meaningful relationship $(\mathrm{r}=.028, \mathrm{p}<.001)$.
\end{abstract}

Keywords Problem Solving, Attitude, Sport

\section{Introduction}

Education involves all kinds of practices aiming to improve individuals' physical, cognitive, affective and social skills, help them develop new attitudes and acquire new knowledge. In this respect, education is a lifelong process (3). Education aims to make intentional changes in the behaviors of individuals. Educational activities, which have been put into practice since ancient times, were initially carried out by the members of families and the elder members of the tribes. As science progressed and knowledge became more sophisticated, teachers and private institutions started to emerge whose main mission was to provide knowledge for individuals through teaching. Since education dates back to the beginning of history, we can conclude that teaching profession is as old as the history of mankind (4).
The main goal of educational activities is to train qualified individuals and teach them about citizenship issues. Thus, educational systems determine desired qualities for an ideal individual according to their prevailing educational philosophies and policies and design their educational practices accordingly. Education is the main concern of all societies and teachers are indispensable elements of this process. Teachers have always been the main elements of each society, science and technological developments. The related research reveals that teachers have pioneered changes in societies, and teaching has been considered more important than others as a profession. Thus, training qualified teachers is a prerequisite for societies to achieve their goals (5). Teaching is one of the most significant professions, and teachers are expected to assume important responsibilities and duties in their jobs. What is essential here is that they should fulfill these responsibilities and duties as effectively as possible.

One of the factors enabling developing countries like Turkey to become a developed country is the presence of well-qualified and well-educated individuals. Therefore; teacher training is also a very important issue in our country, Turkey (6). Employing successful teachers in schools in the future requires quality teacher training programs and putting this quality education into practice effectively. Preservice teachers should also be equipped with the qualities of a good teacher. Such qualities can be classified into two main categories: professional qualities and personal qualities. Professional qualities include knowledge and skills required for teaching profession, some hints for a better teaching process, and classroom management skills while personal qualities involve individuals' orientation to the profession and their role modelling skills for teaching practices (3). In addition, they refer to positive and negative behaviors of individuals about events, situations and objects (7). Positive attitudes regarding teaching profession can be listed as "eagerness to work with young children", "commitment to the profession", "awareness about the importance of education and teaching" while negative attitudes include "reluctance 
to work with young children", "failure to complete self-realization" and "not being enthusiastic and self-sacrificing". Negative attitudes hinder achievement while positive ones result in higher levels of achievement. Therefore, it is important for preservice teachers to be equipped with necessary qualities of a good teacher and receive quality education. One strategy to achieve this purpose is to determine attitudes of preservice teachers towards teaching profession and to help them develop positive ones (8). Obtaining information about preservice teachers' attitudes is an important issue that needs to be considered while planning and deciding on program contents (1). Much research has examined these attitudes in relation with different variables such as age, gender, class level, family income level and educational background of parents. Teachers are expected to have effective problem solving skills in addition to other positive characteristics. Problem solving skill is about the awareness of the gap between a predetermined target and the obstacles encountered while trying to achieve it and fix this gap as effectively as possible (9). According to another definition, problem-solving skill refers to the development of certain skills to find suitable methods to solve a problem and analyze it by using these methods (10). At this point, the most important activity reflecting individuals' problem solving skills is reasoning. Realizing what the problem is triggers this reasoning process, which leads to a proper solution to a specific problem by an individual whose goal is to solve this particular problem (10).

Preservice teachers' positive attitudes towards teaching profession and their effective problem solving skills are believed to have positive effects on students' academic achievement. Thus, it is important for preservice teachers to develop positive attitudes towards teaching and to be equipped with effective problem solving skills. This study examines preservice teachers' attitudes towards teaching profession and their problem solving skills in terms of certain independent variables such as age, gender, class level, family income level and educational background of parents. The discussions based on the findings of this study are expected to contribute to the related literature.

\section{Method}

\subsection{Research Model}

The study used survey method to examine preservice teachers' attitudes towards teaching profession and their problem solving skills according to different variables.
Survey method aims to examine a situation as it exists regardless of being a present or a past one (11). To achieve this purpose, the researcher seeks for Research Model answers to the questions aiming to obtain data about the current status of a situation (3). According to (12), such studies aim to explain the characteristics of a study group, their attitudes towards events and their points of view.

The participants of the study were $1 \mathrm{st}, 2 \mathrm{nd}$, 3rd and 4th year students attending Kastamonu University Physical Education and Sports Teaching Department during the Spring term of 2017-2018 academic year. The total number of participants was 260: 111 female and 149 male.

\subsection{Data Collection Tools}

\section{Scale of Attitudes of Preservice Teachers towards Teaching Profession}

The study used Scale of Attitudes of Preservice Teachers towards Teaching Profession developed by Üstüner (2006). This five-point-Likert type scale consists of 34 items. The validity and reliability studies of the scale were carried out by (1). KMO value of the scale was calculated as 91 , Barlett test as 7835 and internal consistency coefficient as 93. High scores obtained from the scale show a positive attitude and lower scores a negative one. The highest possible score to be obtained from the scale is 170 and the lowest 34.

\subsection{Data Analysis}

The data obtained in the study were analyzed by using SPSS program. Since the data did not show normal distribution, Mann-Whitney test was applied for age and gender variables; and Kruskal Wallis test for mothers' educational background, fathers' educational background, class level and family income variables. Level of significance was taken as .05 for statistical calculations.

\section{Results}

The study examined whether attitudes and problem solving skills of preservice teachers of physical education and sports differ according to the educational background of parents. The correlation analysis revealed significant differences for mothers' educational background and fathers' educational background, but not for other variables. The results are presented in the tables below. 
Table 1. Kruskal Wallis Test Results - Educational Background of Mothers

\begin{tabular}{llccccc}
\hline Scale & Mother's Educational Background & $\mathrm{N}$ & Mean Rank. & sd & $\chi^{2}$ & Multiple Comparison \\
\hline \multirow{5}{*}{ Attitude } & 1) Primary School & 148 & 120,75 & & & \\
& 2) Secondary School & 59 & 141,50 & & &, 015 \\
& 3) High school & 41 & 133,46 & 3 & 10,500 & \\
& 4)Undergraduate and above & 12 & 186,58 & & & \\
\hline
\end{tabular}

$\left(\mathrm{p}^{*}<0,05\right)$

According to Kruskal-Wallis test results, there is a meaningful difference in "mother's educational background" variable $(\mathrm{p}<.05)$ at "primary school" and "undergraduate and above" education levels. The Mean scores of undergraduate and above educational level graduate mothers for attitude scores are higher than those of primary school group.

Table 2. Kruskal Wallis Test Results - Educational Background of Fathers

\begin{tabular}{ccccccc}
\hline Scale & Father's Educational Background & $\mathrm{N}$ & Mean Rank. & sd & $\chi^{2}$ & Multiple Comparison \\
\hline \multirow{3}{*}{ Attitude } & 1) Primary School & 104 & 124,93 & & & \\
& 2) Secondary School & 65 & 114,27 & & &, 021 \\
& 3) High School & 59 & 142,69 & 3 & 9,781 & \\
\hline
\end{tabular}

$\left(\mathrm{p}^{*}<0,05\right)$

Kruskal-Wallis test results showed that there is a meaningful difference in "fathers' educational background" variable $(\mathrm{p}<.05)$ at "secondary school" and "undergraduate and above" education levels. The Mean scores of undergraduate and above educational level graduate fathers for attitude scores are higher than those of primary school group.

Table 3. Correlation Table

\begin{tabular}{ccc}
\hline & & Solving \\
\hline \multirow{3}{*}{ Attitude } & Correlation Coefficient & .281 \\
& $\mathrm{P}$ &, 000 \\
$\mathrm{~N}$ & 260 \\
\hline
\end{tabular}

The correlation analysis for attitudes and problem solving skills revealed a low level meaningful linear relationship between these two dependent variables $(\mathrm{r}=, 281 ; \mathrm{p}<, 05)$.

\section{Discussion}

This section presents the discussions and conclusions obtained from the findings of the study focusing on the attitudes and problems solving skills of the students attending Kastamonu University School of Physical Education and Sports in terms of different variables.

According to the results of Kruskal-Wallis test, a significant difference was found between attitudes of preservice teachers towards teaching profession and "educational background of mothers"; mainly at "primary school" and "undergraduate and above" education levels. This result shows that the mothers who are graduates of undergraduate and above education programs develop a more positive attitude towards teaching professions than the primary school graduate mothers. This finding is consistent with the finding of the study conducted by (3); however, it contradicts with that of the study by (13). The analyses regarding the educational background of fathers for the same variable also revealed a significant difference at "secondary school" and "undergraduate and above" education levels. Accordingly, the fathers who are graduates of undergraduate and above education programs have a more positive attitude towards teaching professions than the secondary school graduate fathers. This finding is in parallel with the finding of the study conducted by (13); but not with the findings of the studies carried out by (3) and (14).

The Analyses seeking for a significant difference in the variable "gender" did not reveal any significant differences. This finding is not consistent with the findings of the studies conducted by $(3,5,7,13,14,15,16,17,18)$ but in parallel with the finding of the study by (19).

The analysis regarding the variable "class level" also revealed no significant differences, which is consistent with the finding of the study conducted by (13). (20) in their study, found: " $1^{\text {st }}$ year students have higher attitude towards teaching profession that $2^{\text {nd }}$ year students, which results in a significant difference between $1^{\text {st }}$ and $2^{\text {nd }}$ year students". Although this finding is not consistent with the findings of our study, the fact that they did not find a significant difference between $3^{\text {rd }}$ and $4^{\text {th }}$ year students are in parallel with the findings of our study.

Similarly, no significant difference was found for preservice teachers' attitudes towards teaching profession regarding the variable "family income", which is 
consistent with the findings of the studies by $(13,20,21)$.

Finally, the variable "age" was examined to see whether preservice teachers' attitudes towards teaching profession differs or not, and no significant difference was found. This result is consistent with the finding of the study by (5), but not with the study conducted by (18).

In conclusion, the study reveals that the parents who are graduates of undergraduate and above education levels, i.e well-educated parents, have more positive attitudes towards teaching profession. The reason why no significant differences were found for the variables "family income, class level, age and gender" might be low number of sampling. Thus, higher number of sampling might produce different results

\section{Recommendations}

This study was conducted at Kastamonu University School of Physical Education and Sports. Similar studies might be carried out at different universities with the students attending Sports Faculties in order to create a general profile for attitudes towards teaching profession and problem solving skills.

\section{REFERENCES}

[1] Üstüner, M. (2006). Öğretmenlik Mesleğine Yönelik Tutum Ölçeğinin Geçerlik ve Güvenirlik Çalışması. Kuram ve Uygulamada Eğitim Yönetimi, (45), 109-127.

[2] Sahin, N., Sahin, N. H. ve Heppner, P. P. (1993). Psychometric properties of the problem solving inventory in a group of Turkish university students. Cognitive Therapy and Research, 17(4), 379-396. doi:10.1007/BF01177661

[3] Aydın, R. ve Sağlam, G. (2012). Öğretmen Adaylarının Öğretmenlik Mesleğine Yönelik Tutumlarının Belirlenmesi (Mehmet Akif Ersoy Üniversitesi Örneği). Türk Eğitim Bilimleri Dergisi, 10 (2), 257-294.

[4] Oktay, A. (1991). Öğretmenlik Mesleği Ve Öğretmenin Nitelikleri. M.Ü. Atatürk Eğitim Fakültesi Eğitim Bilimleri Dergisi.

[5] Durmuş, M., Sayg1, E. ve Yıldız, N. (2017). Öğretmen Adaylarının Ögretmenlik Mesleğine İlişkin Tutumlarının Bazı Değişkenler Açısından Incelenmesi Investigation of Teacher Candidates ', Attitudes towards Teaching Profession. Uluslararası Toplum Araştırmaları Dergisi, 7(12), 10-31.

[6] Üstün, E., Erkan, S. ve Akman, B. (2002). Türkiye'de Okul Öncesi Öğretmenliği Öğrencilerinin Öğretmenlik Mesleğine Yönelik Tutumlarının İncelenmesi. Hacettepe Üniversitesi, Eğitim Fakültesi, 131-135.

[7] Çapri, B. ve Çelikkaleli, Ö. (2008). Öğretmen Adaylarının Ögretmenliğe Ilişkin Tutum Ve Mesleki Yeterlik Inançlarının Cinsiyet, Program Ve Fakültelerine Göre Incelenmesi. İnönü Üniversitesi Eğitim Fakültesi Dergisi,
9(15), 33-53. doi:10.17679/IUEFD.18403

[8] Semerci, N. ve Semerci, Ç. (2004). Türkiye'de Öğretmenlik Tutumlarl. Frrat Üniversitesi Sosyal Bilimler Dergisi, 14(1), 137-146.

[9] Yenice, N. (2012). Öğretmen Adaylarının Özyeterlik Düzeyleriyle Problem Çözme Becerilerinin Incelenmesi. Elektronik Sosyal Bilimler Dergisi, 11(39), 036-058.

[10] Ocak, G. ve Eğmir, E. (2014). Öğretmen Adaylarının Problem Çözme Becerilerinin Çeșitli Değişkenler Açısından Incelenmesi. Asya Öğretim Dergisi, 2, $27-45$.

[11] Karasar, N. (2009). Bilimsel araştırma yöntemi (19. Baskı), Ankara, Nobel basımevi

[12] Büyüköztürk, Ş., Çakmak, E. K., Akgün, Ö. E., Karadeniz, Ş. ve Demirel, F. (2011). Bilimsel Araştırma Yöntemleri (9.Baskl), Ankara, Pegem Akademi Yayınları

[13] Pehlivan, B. K. (2008). Sinıf Öğretmeni Adaylarının Sosyo-kültürel Özellikleri ve Öğretmenlik Mesleğine Yönelik Tutumları Üzerine Bir Çalışma. Mersin University Journal of the Faculty of Education. doi:10.17860/EFD.30656

[14] Köğce, D., Aydın, M. ve Yıldız, C. (2010). Birinci ve Dördüncü Sinıf Matematik Öğretmen Adaylarının Öğretmenlik Mesleğine Karşı Tutumları - Freshman and Senior Pre-service Mathematics Teachers' Attitudes Toward Teaching Profession. The International Journal of Research in Teacher Education, Öğretmen Eğitiminde uluslararası araştırma dergisi 2(1), 2-16.

[15] Tay, B. ve Tay, A. B. (2008). Sosyal Bilgiler Dersine Yönelik Tutumun Başarıya Etkisi, 6(4), 603-627.

[16] Capa, Y. ÇiL, N. (2000). Öğretmen Adaylarının Ögretmenlik Mesleğine Yönelik Tutumlarının Farklı Deglşkenler Açısından İncelenmesi. Hacettepe Üniversitesi Ĕ̈itim Fakültesi Dergisi, 18 , 69-73.

[17] Engin, G. ve Göksu, K. (2006). Öğretmen Adaylarinin Ögrretmenlik Mesleğine Yönelik Tutumları,18, 153-168.

[18] Cinpolat, T., Alıncak, F. ve Abakay, U. (2016). Beden Ĕgitimi Ve Spor Yüksekokulu Öğrencilerinin Ögrretmenlik Mesleğine Yönelik Tutumlarının İncelenmesi. Spor Bilimler Dergisi, 1(1), 38-47.

[19] Bulut, H. ve Doğar, Ç. (2006). Öğretmen Adaylarının Öğretmenlik Mesleğine Karşı Tutumlarının Incelenmesi. Erzincan Üniversitesi Eğitim Fakültesi Dergisi, 8(2), $13-27$.

[20] Uğurlu, C. ve Polat, S. (2011). Sinıf Öğretmenliği Öğrencilerinin Öğretmenlik Mesleğine İlişkin Tutumları. Cumhuriyet Üniversitesi Edebiyat Fakültesi Sosyal Bilimler Dergisi, 35(1), 68-74.

http://dergipark.gov.tr/cumusosbil/issue/4344/59383 adresinden erişildi.

[21] Güleçen, S., Cüro, E. ve Semerci, N. (2008). Anadolu Ögrretmen Lisesi Ögrrencilerinin Ögrretmenlik Mesleğine İlişkin Tutumları. Fırat Üniversitesi Sosyal Bilimler Dergisi, 18(1), 139-157. i This stuy was orally presented in $1^{\text {st }}$ International Congress of Physical
Education, Sport, Recreation and Dance (26-28 April 2018), Nişantaş1 University, Turkey. 